\title{
Growth and Production of Young Peach Trees Irrigated by Furrow, Microjet, Surface Drip, or Subsurface Drip Systems
}

\author{
David R. Bryla ${ }^{1}$, Thomas J. Trout, and James E. Ayars \\ U.S. Department of Agriculture, Agricultural Research Service, Water \\ Management Research Laboratory, 9611 S. Riverbend Avenue, Parlier, \\ CA 93648
}

\section{R. Scott Johnson \\ University of California Kearney Agricultural Center, 9240 S. Riverbend Avenue, Parlier, CA 93648}

\begin{abstract}
Additional index words. evapotranspiration, microirrigation, Prunus persica, soil water
\end{abstract} content, vegetative growth

\begin{abstract}
A 3-year study was conducted in central California to compare the effects of furrow, microjet, surface drip, and subsurface drip irrigation on vegetative growth and early production of newly planted 'Crimson Lady' peach [Prunus persica (L.) Batsch] trees. Furrow treatments were irrigated every 7, 14, or 21 days; microjet treatments were irrigated every $2-3,7$, or 14 days; and surface and subsurface drip (with one, two, or three buried laterals per row) treatments were irrigated when accumulated crop evapotranspiration reached $2.5 \mathrm{~mm}$. The overall performance showed that trees irrigated by surface and subsurface drip were significantly larger, produced higher yields, and had higher water use efficiency than trees irrigated by microjets. In fact, more than twice as much water had to be applied to trees with microjets than to trees with drip systems in order to achieve the same amount of vegetative growth and yield. Yield and water use efficiency were also higher under surface and subsurface drip irrigation than under furrow irrigation, although tree size was similar among the treatments. Little difference was found between trees irrigated by surface and subsurface drip, except that trees irrigated with only one subsurface drip lateral were less vigorous, but not less productive, than trees irrigated by one surface drip lateral, or by two or three subsurface drip laterals. Within furrow and microjet treatments, irrigation frequency had little effect on tree development and performance with the exception that furrow irrigation every 3 weeks produced smaller trees than furrow irrigation every 1 or 2 weeks.
\end{abstract}

Irrigating young peach trees during the first few years of orchard establishment is a critical practice in most commercial growing regions of the United States. Ideally, enough water is applied to replace any water lost by crop evapotranspiration and to prevent any limitation to growth (Johnson et al., 2002; Renquist, 1987). Inadequate irrigation reduces canopy development and lengthens the time to reach full production, while over-irrigation limits root development and can lead to groundwater contamination by leaching of soil nitrates and pesticides (Syvertsen, 1986).

Received for publication 29 July 2002. Accepted for publication 4Feb. 2003. Research was funded in part by the California State Univ. Agriculture Research Initiative. The technical assistance of Robert Shenk and Jim Gartung are greatly appreciated. Mention of trade or manufacturer names is made for information only and does not imply endorsement or exclusion by the USDA-ARS.

${ }^{1}$ To whom reprint requests should be addressed. Current address: USDA-ARS Horticultural Crops Research Laboratory, 3420 NW Orchard Ave., Corvallis, OR 97330. E-mail: brylad@onid.orst.edu
Traditionally, peach and other fruit trees have been irrigated by surface methods, which include basin, border, and furrow systems. Surface systems are relatively simple and inexpensive to install and have produced reasonable results in good quality soils with flat topography. The downside of these systems is that surface methods require high labor input during irrigation, and distribution of water can vary considerably within the field, resulting in low irrigation uniformity and efficiency (defined as the ratio of the volume of irrigation water beneficially used by the crop as evapotranspiration in a specified area to the volume of water delivered to this area) (Kruse et al., 1990). For this reason, pressurized irrigation systems in orchards are becoming increasingly popular. Pressurized systems include sprinkler systems and low-volume systems, such as microjet, surface drip, and subsurface drip systems. Low-volume systems, in particular, offer many potential advantages over surface systems, including improved water control and distribution uniformity, enhanced plant growth and yield, improved application of fertilizer and other chemicals, reduced salinity hazard, reduced weed control costs, and improved cultural practices (Kruse et al., 1990). Subsurface drip systems may further improve irrigation and fertilizer use efficiency because water and nutrients are applied directly to the root zone (Camp, 1998). Disadvantages of pressurized systems include higher capital and energy costs and increased maintenance requirements. Currently, there are $\approx 20,600$ ha of peach, nectarine, and apricot orchards irrigated by surface systems and 31,300 ha irrigated by pressurized systems, most of which are sprinkler and microjet systems, in California (Burt et al., 2002).

The objective of this study was to evaluate the potential of various irrigation systems and scheduling strategies to improve vegetative growth and early production of young peach trees. We hypothesized that the trees would develop faster and produce significantly more fruit early on when irrigated with low-volume, pressurized systems than with surface systems, due to more precise water application. We also hypothesized that frequent irrigations (e.g., irrigations every 1 to $3 \mathrm{~d}$ ) would be more beneficial to tree performance than less frequent irrigations (e.g., weekly irrigations or greater) because the latter would expose trees to short-term periods of water stress during each irrigation cycle (Fereres and Goldhamer, 1990).

\section{Materials and Methods}

Study site. The research was conducted on a 1.6-ha plot of early-ripening 'Crimson Lady' peach trees on 'Nemaguard' rootstock planted in Apr. 1999 at the USDA-ARS San Joaquin Valley Agricultural Sciences Center located in Parlier, Calif. Trees had $\approx 2-\mathrm{cm}$ basal stem diameters and were pruned $60 \mathrm{~cm}$ high at planting. Soil at the site is a Hanford fine sandy loam overlying a dense hardpan layer located 1.9 to $2.1 \mathrm{~m}$ deep. Trees were spaced $1.8 \mathrm{~m}$ apart in 4.9- $\mathrm{m}$ rows and pruned to a perpendicular- $\mathrm{V}$ training system (DeJong et al., 1994).

Experimental design. Ten different main irrigation treatments consisting of three furrow, three microjet, one surface drip, and three subsurface drip treatments were arranged at the site in a randomized complete-block design. A description of each treatment is listed in Table 1. Furrow treatments were flood irrigated in 1-m wide $\times 15$-m long furrows located on each side of the row, $0.5 \mathrm{~m}$ from the tree trunks. Microjet treatments were irrigated with one $20 \mathrm{~L} \cdot \mathrm{h}^{-1}$ emitter $\left(\approx 3.0\right.$-m diameter, $230^{\circ}$ spray pattern; Bowsmith, Exeter, Calif.) located near the base of each tree. The microjet emitters were covered with "top hat" throw limiters during the first 4 months following planting, which deflected the irrigation water downwards and concentrated it close to the trees. Once trees were established and their root systems were developed, the "top hats" were removed in order to wet the entire soil surface area beneath the trees and encourage broader root development. Drip tubing (GeoFlow, Charlotte, N.C.), with $2 \mathrm{~L} \cdot \mathrm{h}^{-1}$ integral turbulent flow emitters spaced $0.45 \mathrm{~m}$ apart, was used for the surface drip and subsurface drip treatments; a description of the lateral placement is provided in Table 1. 
Subsurface drip treatments were irrigated by surface drip the first year and then switched to subsurface drip the second year once the trees were established. Subsurface drip tubing was buried $0.45 \mathrm{~m}$ deep.

There were six replicate blocks per treatment and each plot consisted of three rows of eight trees. For most of the treatments, all three rows were irrigated at scheduled intervals to replace $100 \%$ of the crop evapotranspiration $\left(\mathrm{ET}_{\mathrm{c}}\right.$ ) requirements (see below), and measurements were made on the middle six trees of the center row only. However, in three of the treatments - one furrow, one microjet, and one subsurface drip - the border rows were randomly assigned to irrigate at $70 \%$ or $150 \% \mathrm{ET}_{c}$, and measurements were made on the middle six trees of all three rows (see footnote in Table 1). It was assumed that border treatments would not influence main treatments in the center row when trees were young and the root systems were not fully developed. Irrigation treatments were initiated 11 June 1999 and continued for three seasons until 15 Oct. 2001.

Orchard management. Irrigations were scheduled based on hourly $\mathrm{ET}_{\mathrm{c}}$ measurements made on well-watered peach trees growing in a weighing lysimeter. This approach used actual tree water use data, making it relatively easy, especially with drip and microjet irrigation, to apply water to match the $\mathrm{ET}_{\mathrm{c}}$ throughout the season. The lysimeter was located in a 1.4-ha peach field $\approx 0.5 \mathrm{~km}$ from the site and contained two trees of the same variety/rootstock, age, planting density, and training system as trees grown in the present study (see Johnson et al., 2002, for details). To avoid poor distribution uniformity, furrow treatments were not scheduled when cumulative $\mathrm{ET}_{\mathrm{c}}$ was less than $10 \mathrm{~mm}$ and microjet treatments were not scheduled when cumulative $\mathrm{ET}_{\mathrm{c}}$ was less than $5 \mathrm{~mm}$. Under these circumstances, any residual $\mathrm{ET}_{\mathrm{c}}$ was applied during the following scheduled irrigation.

Trees were fertilized with UN32 at a rate of $\mathrm{N}$ at $45 \mathrm{~kg} \cdot \mathrm{ha}^{-1}$ during the first growing season and $60 \mathrm{~kg} \cdot \mathrm{ha}^{-1}$ during the second and third seasons; the fertilizer was shanked into the furrows in three equal doses applied in May, June, and July, and was continuously injected from April to August into the microjet and drip irrigation systems. Trees were summer pruned in June and dormant pruned in January each year. All fruit were removed from the trees in April the second season after planting and thinned to 50-100 fruit per tree the third season after planting; fruit were commercially harvested the third season in two pickings in late May. Weeds, insects, and diseases were controlled with herbicides and pesticides as needed.

Measurements. Precipitation at the site was measured with a rain gauge (Campbell Scientific, Logan, Utah) located in an adjacent crop field. Irrigation was monitored daily with turbine water meters (Models SR-II and W-120, Invensys Metering Systems, Uniontown, Pa.) installed at the inflow to each treatment system. Summer and dormant pruning weights were measured following each commercial hand pruning. Trunk cross-sectional areas were estimated each October by measuring trunk
Table 1. Irrigation treatments applied to young 'Crimson Lady' peach trees during the first 3 years (1999-2001) following planting.

\begin{tabular}{|c|c|}
\hline Treatment & Description \\
\hline Furrow (7 d) & Furrow irrigated every $7 \mathrm{~d}$ \\
\hline Furrow $(14 d)^{2}$ & Furrow irrigated every $14 \mathrm{~d}$ \\
\hline Furrow (21 d) & Furrow irrigated every $21 \mathrm{~d}$ \\
\hline Microjet (2-3/week $)^{2}$ & Irrigated with microjets $2-3$ times per week \\
\hline Microjet (7 d) & Irrigated with microjets every $7 \mathrm{~d}$ \\
\hline Microjet (14 d) & Irrigated with microjets every $14 \mathrm{~d}$ \\
\hline Surface drip & $\begin{array}{l}\text { Irrigated with one lateral of drip tubing every time } 2.5 \mathrm{~mm} \text { of water } \\
\text { was evapotranspired; the lateral was placed on the soil surface near } \\
\text { the tree trunks along the row. }\end{array}$ \\
\hline SDI (one lateral) & $\begin{array}{l}\text { Irrigated with one lateral of subsurface drip tubing every time } 2.5 \mathrm{~mm} \\
\text { of water was evapotranspired; the lateral was centered between rows } \\
\text { at a distance of } 2.4 \mathrm{~m} \text { from the tree trunks. }\end{array}$ \\
\hline SDI (two laterals) ${ }^{2}$ & $\begin{array}{l}\text { Irrigated with two laterals of subsurface drip tubing every time } 2.5 \mathrm{~mm} \\
\text { of water was evapotranspired; laterals were located on each side of } \\
\text { the row at a distance of } 1.1 \mathrm{~m} \text { from the tree trunks. }\end{array}$ \\
\hline SDI (three laterals) & $\begin{array}{l}\text { Irrigated with three laterals of subsurface drip tubing every time } 2.5 \mathrm{~mm} \\
\text { of water was evapotranspired; laterals were located on each side of } \\
\text { the row at a distance of } 1.1 \mathrm{~m} \text { from the tree trunks and centered between } \\
\text { the rows at a distance of } 2.4 \mathrm{~m} \text { from the tree trunks. }\end{array}$ \\
\hline
\end{tabular}

Table 2. Crop evapotranspiration $\left(\mathrm{ET}_{\mathrm{c}}\right)$, precipitation, and irrigation applied to young 'Crimson Lady' peach trees during the first 3 years (1999-2001) following planting.

\begin{tabular}{|c|c|c|c|c|c|c|c|c|c|}
\hline \multirow[b]{2}{*}{ Month } & \multicolumn{3}{|c|}{$\mathrm{ET}_{\mathrm{c}}(\mathrm{mm})^{\mathrm{z}}$} & \multicolumn{3}{|c|}{ Precipitation (mm) } & \multicolumn{3}{|c|}{ Irrigation $(\mathrm{mm})^{\mathrm{y}}$} \\
\hline & 1999 & 2000 & 2001 & 1999 & 2000 & 2001 & 1999 & 2000 & 2001 \\
\hline January & --- & 5 & 4 & 93 & 64 & 52 & --- & 0 & 0 \\
\hline February & --- & 16 & 8 & 28 & 120 & 43 & --- & 0 & 0 \\
\hline March & --- & 22 & 23 & 14 & 42 & 20 & --- & 0 & 0 \\
\hline April & $15^{\mathrm{x}}$ & 28 & 41 & 34 & 27 & 43 & 0 & 11 & 23 \\
\hline May & 17 & 46 & 86 & 7 & 7 & 0 & 0 & 38 & 86 \\
\hline June & 24 & 76 & 107 & 2 & 22 & 0 & 26 & 56 & 108 \\
\hline July & 38 & 94 & 157 & 0 & 0 & 20 & 38 & 91 & 139 \\
\hline August & 51 & 101 & 175 & 0 & 0 & 0 & 50 & 99 & 175 \\
\hline September & 64 & 86 & 135 & 5 & 0 & 0 & 58 & 84 & 135 \\
\hline October & 38 & 34 & 82 & 0 & 43 & 8 & 24 & 10 & 42 \\
\hline November & 11 & 7 & 17 & 15 & 3 & 42 & 0 & 0 & 0 \\
\hline December & 2 & 1 & 5 & 0 & 0 & 64 & 0 & 0 & 0 \\
\hline Total & 260 & 516 & 840 & 198 & 328 & 292 & 196 & 389 & 708 \\
\hline
\end{tabular}

${ }^{2}$ Measured with a weighing lysimeter.

'yrrigations were applied 10 June-20 Oct.1999, 5 Apr.-6 Oct. 2000, and 11 Apr.-15 Oct. 2001.

${ }^{x}$ Trees were planted 10 Apr. 1999.

Table 3. Trunk cross sectional area (TCSA) and fresh pruning weights of young 'Crimson Lady' peach trees irrigated by furrow, microjet, surface drip, or subsurface drip irrigation (SDI) systems during the first 3 years (1999-2001) following planting.

\begin{tabular}{|c|c|c|c|c|c|c|}
\hline \multirow[b]{2}{*}{ Treatment } & \multicolumn{3}{|c|}{$\operatorname{TCSA}\left(\mathrm{cm}^{2}\right)^{2}$} & \multicolumn{3}{|c|}{ Pruning wt $(\mathrm{kg} / \text { tree })^{\mathrm{y}}$} \\
\hline & 1999 & 2000 & 2001 & 1999 & 2000 & 2001 \\
\hline Furrow (7 d) & 9.3 & $30.2 \mathrm{a}-\mathrm{c}^{\mathrm{x}}$ & $53.3 \mathrm{ab}$ & 1.02 & $4.62 \mathrm{a}-\mathrm{c}$ & $9.21 \mathrm{bc}$ \\
\hline Furrow (14 d) & 8.9 & $30.6 \mathrm{a}-\mathrm{c}$ & $55.0 \mathrm{a}$ & 1.02 & $5.29 \mathrm{a}$ & $9.02 b-d$ \\
\hline Furrow (21 d) & 9.0 & $28.6 \mathrm{a}-\mathrm{c}$ & $48.5 \mathrm{bc}$ & 1.07 & $4.37 \mathrm{a}-\mathrm{c}$ & $7.59 \mathrm{~d}$ \\
\hline Microjet (2-3/week) & 9.3 & $26.5 \mathrm{c}$ & $40.6 \mathrm{~d}$ & 1.03 & $3.81 \mathrm{c}$ & $5.99 \mathrm{e}$ \\
\hline Microjet (7 d) & 9.2 & $27.5 \mathrm{bc}$ & $41.9 \mathrm{~d}$ & 0.95 & $4.06 \mathrm{a}-\mathrm{c}$ & $5.70 \mathrm{e}$ \\
\hline Microjet (14 d) & 9.0 & $27.8 \mathrm{bc}$ & $44.7 \mathrm{~cd}$ & 0.85 & $4.34 \mathrm{a}-\mathrm{c}$ & $6.14 \mathrm{e}$ \\
\hline Surface drip & 9.7 & $31.5 \mathrm{ab}$ & $55.4 \mathrm{a}$ & 1.12 & $4.82 \mathrm{a}-\mathrm{c}$ & $10.71 \mathrm{a}$ \\
\hline SDI (one lateral) & 9.3 & $31.1 \mathrm{a}-\mathrm{c}$ & $51.2 \mathrm{ab}$ & 1.01 & $4.00 \mathrm{bc}$ & $7.78 \mathrm{~cd}$ \\
\hline SDI (two laterals) & 10.5 & $33.0 \mathrm{a}$ & $56.8 \mathrm{a}$ & 1.28 & $5.07 \mathrm{ab}$ & $9.97 \mathrm{ab}$ \\
\hline \multirow[t]{2}{*}{ SDI (three laterals) } & 10.2 & $32.3 \mathrm{ab}$ & $56.0 \mathrm{a}$ & 1.13 & $4.73 \mathrm{a}-\mathrm{c}$ & $10.02 \mathrm{ab}$ \\
\hline & \multicolumn{6}{|c|}{ Contrasts $(P>F)$} \\
\hline Furrow vs. microjet & 0.8766 & 0.0477 & 0.0001 & 0.4424 & 0.0296 & 0.0001 \\
\hline Furrow vs. surface drip and SDI & 0.1485 & 0.0624 & 0.1205 & 0.3758 & 0.7125 & 0.0084 \\
\hline $\begin{array}{l}\text { Microjet vs. surface drip } \\
\text { and SDI }\end{array}$ & 1991 & ברח000 & $0 \Omega 001$ & 00917 & 00482 & 00001 \\
\hline Surface drip vs. SDI & 0.7604 & 0.7025 & 0.7483 & 0.9294 & 0.6105 & 0.0124 \\
\hline
\end{tabular}

${ }^{2}$ Measured at the end of the growing season.

${ }^{y}$ Summer and dormant pruning weights combined.

${ }^{x}$ Within a column, means followed by the same letter are not significantly different at $P \leq 0.05$ using Duncan's multiple range test. 
circumferences at $20 \mathrm{~cm}$ above the soil surface. Fruit were counted and weighed at harvest.

Statistical analysis. All data were subjected to analysis of variance (ANOVA) using ProcGLM (SAS Institute, Cary, N.C.) and means were separated at the 0.05 level using Duncan's multiple range test. Planned contrasts were also conducted using ProcGLM to compare groups of treatments.

\section{Results}

Irrigation requirements. Crop evapotranspiration estimated from measurements made on the weighing lysimeter indicated that the newly planted trees required 233, 441, and $743 \mathrm{~mm}$ of water during the first three growing seasons (March through October), respectively (Table 2). In comparison, mature peach trees grown in central California require $\approx 850 \mathrm{~mm}$ of irrigation each year on average (Goldhamer and Snyder, 1989). Thus, by the third season, the young trees appeared to have nearly reached their expected full transpiration potential based on the average tree requirements.

Winter precipitation was adequate to fully recharge the soil water profile at the beginning of each growing season. However, during each growing season, only $5 \%$ to $12 \%$ of the estimated water required for evapotranspiration was provided by precipitation (Table 2). Summer precipitation in particular was limited, which is typical for central California. Any additional water requirements were supplemented by irrigation with the highest irrigation requirements occurring in September the first season, and in August the following two seasons (Table 2).

Irrigations were applied as scheduled throughout each growing season unless a substantial rainfall occurred. Furrow irrigations were typically applied in less than $30 \mathrm{~min}$ while microjet irrigations usually required anywhere from 2 to $9 \mathrm{~h}$, depending on the treatment and the time of year. Microjet sets never ran for more than $12 \mathrm{~h}$ at any given time. Drip and subsurface drip treatments were irrigated every 1 to $3 \mathrm{~d}$ during the first two growing seasons, and required as many as two to three irrigation sets ( $2.5 \mathrm{~mm}$ each) per day during the summer months of the third growing season. Frequent irrigations were required for the subsurface drip treatments in order to apply sufficient water during peak water demand periods (up to $66 \mathrm{~L}$ of water per tree per day), and to prevent water from seeping upward and ponding on the soil surface. Ponding, however, was unavoidable when trees were irrigated with only one subsurface drip lateral located between rows. Ponding was also observed with two drip laterals when irrigation was applied at $150 \% \mathrm{ET}_{\mathrm{c}}$.

Vegetative growth. Trunk cross-sectional area of the young peach trees was not significantly affected by irrigation method during the first year after planting, but was significantly affected in the second $(P=0.048)$ and third $(P$ $<0.001)$ seasons. Irrigation method also had a significant main effect on the fresh pruning weights by the third season $(P<0.001)$. In general, trees irrigated by microjets were significantly smaller than trees irrigated by other

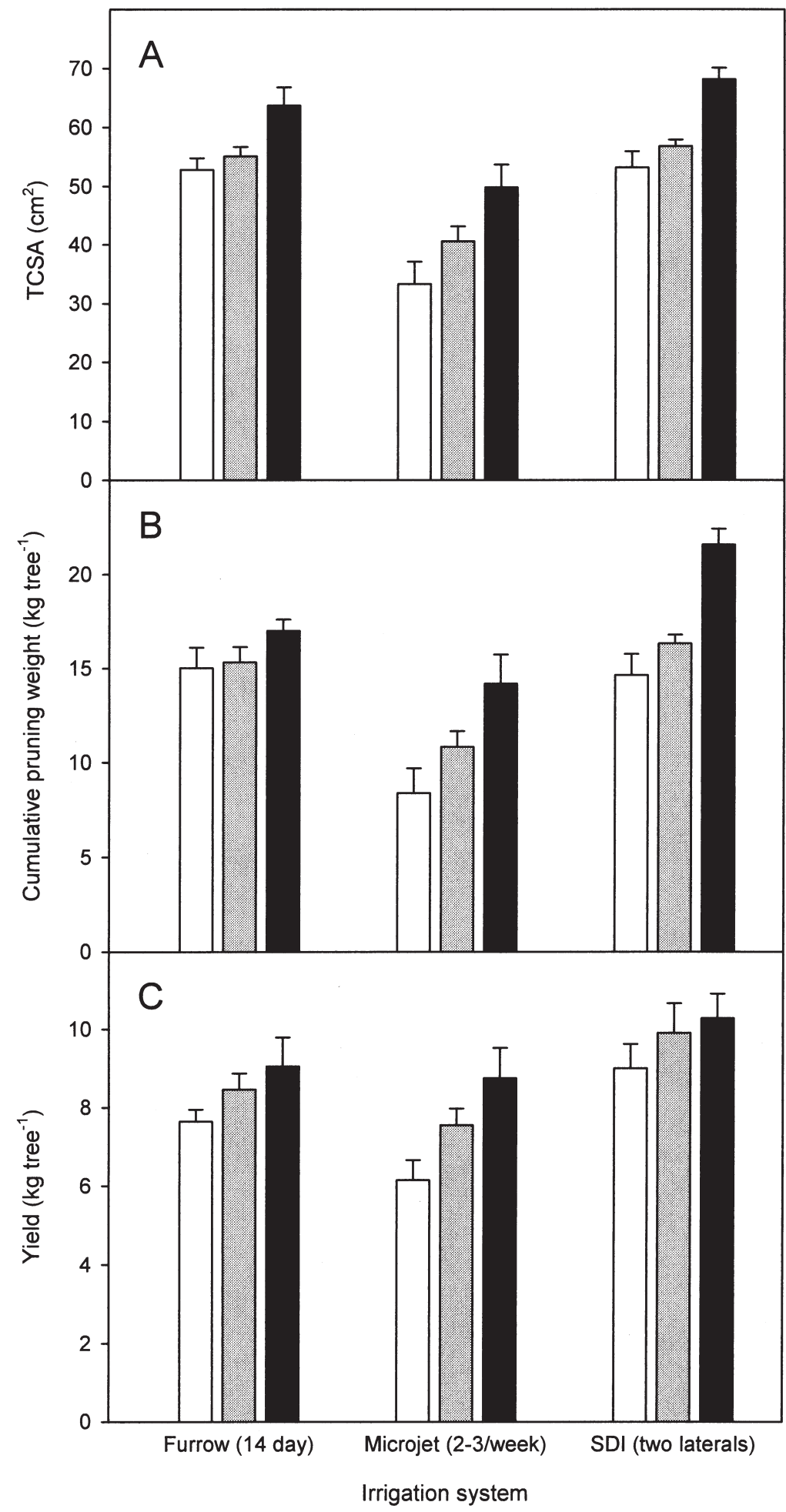

Fig. 1. (A) Trunk cross-sectional area (TCSA), (B) cumulative pruning weight, and (C) yield of 'Crimson Lady' peach trees irrigated by furrow, microjet, or subsurface drip irrigation (SDI) systems at $70 \%$ ( $\square$ ), $100 \%$ (口), $150 \%$ ( $\mathbf{\square}) \mathrm{ET}_{\mathrm{c}}$. Trees were in their third season. Values are the mean of six replicates and error bars represent SE. According to two-way ANOVA procedures, the effects of irrigation method and irrigation level on TCSA, pruning weight, and yield were significant at $P<0.001$, while method $\times$ level interactions were nonsignificant.

methods (Table 3). For example, in trees irrigated at $100 \% \mathrm{ET}_{\mathrm{c}}$, trunk cross-sectional areas averaged 52 and $55 \mathrm{~cm}^{2}$ by the end of year 3 in the furrow and drip treatments, respectively, and only $42 \mathrm{~cm}^{2}$ in the microjet treatments. Cumulative pruning weights, which were highly correlated with trunk cross-sectional area $\left(\mathrm{y}=0.004 \mathrm{x}^{2}+0.088 \mathrm{x}-0.130, \mathrm{r}^{2}=0.89\right.$, $P<0.001$ ), averaged $14.4,16.6$, and $15.0 \mathrm{~kg} /$ tree in the furrow, surface drip, and subsurface drip treatments, respectively, and only 11.0 $\mathrm{kg} /$ tree in the microjet treatments. Even when trees were irrigated by microjets at $150 \% \mathrm{ET}_{\mathrm{c}}$, trunk cross-sectional area and pruning weights 
Table 4. Crop load, fruit size, and yield of young 'Crimson Lady' peach trees irrigated by furrow, microjet, surface drip, or subsurface drip irrigation (SDI) systems. Trees were in their third season.

\begin{tabular}{lccc}
\hline Treatment & $\begin{array}{c}\text { Crop load } \\
\text { (fruit/tree) }\end{array}$ & $\begin{array}{c}\text { Fruit size } \\
(\mathrm{g} / \text { fruit })\end{array}$ & $\begin{array}{c}\text { Yield } \\
(\mathrm{kg} / \mathrm{tree})\end{array}$ \\
\hline Furrow (7 d) & $68 \mathrm{ab}^{\mathrm{z}}$ & $133 \mathrm{c}$ & $8.91 \mathrm{a}-\mathrm{d}$ \\
Furrow (14 d) & $58 \mathrm{~b}$ & $148 \mathrm{a}$ & $8.46 \mathrm{~b}-\mathrm{d}$ \\
Furrow (21 d) & $71 \mathrm{ab}$ & $131 \mathrm{c}$ & $9.22 \mathrm{a}-\mathrm{d}$ \\
Microjet (2-3/week) & $56 \mathrm{~b}$ & $135 \mathrm{bc}$ & $7.55 \mathrm{~cd}$ \\
Microjet (7 d) & $54 \mathrm{~b}$ & $131 \mathrm{c}$ & $7.03 \mathrm{~d}$ \\
Microjet (14 d) & $58 \mathrm{~b}$ & $135 \mathrm{bc}$ & $7.83 \mathrm{~b}-\mathrm{d}$ \\
Surface drip & $75 \mathrm{a}$ & $142 \mathrm{a}-\mathrm{c}$ & $10.60 \mathrm{a}$ \\
SDI (one lateral) & $69 \mathrm{ab}$ & $141 \mathrm{a}-\mathrm{c}$ & $9.55 \mathrm{a}-\mathrm{d}$ \\
SDI (two laterals) & $68 \mathrm{ab}$ & $146 \mathrm{ab}$ & $9.91 \mathrm{a}-\mathrm{c}$ \\
SDI (three laterals) & $70 \mathrm{ab}$ & $146 \mathrm{ab}$ & $10.25 \mathrm{ab}$ \\
& & Contrasts $(P>F)$ & \\
Furrow vs. microjet & 0.0726 & 0.2209 & 0.0446 \\
Furrow vs. surface drip and SDI & 0.2484 & 0.0218 & 0.0437 \\
Microjet vs. surface drip and SDI & 0.0036 & 0.0007 & 0.0001 \\
Surface drip vs. SDI & 0.3714 & 0.7663 & 0.4007 \\
\hline
\end{tabular}

${ }^{2}$ Within a column, means followed by the same letter are not significantly different at $P \leq$ 0.05 using Duncan's multiple range test.

were smaller than for trees irrigated at $70 \%$ $\mathrm{ET}_{\mathrm{c}}$ by furrow and subsurface drip (Fig. $1 \mathrm{~A}$ and $\mathrm{B})$. This indicates that trees irrigated by microjets required more than twice as much irrigation to achieve the same amount of vegetative growth as trees irrigated by furrow or subsurface drip.

By the end of the third growing season, tree size was also significantly affected by irrigation frequency in the furrow irrigation treatments and by the number of drip laterals in the subsurface drip irrigation treatments (Table 3). In particular, trunk cross-sectional areas and pruning weights were greater in trees irrigated by furrow every 7 or $14 \mathrm{~d}$ than in trees irrigated every $21 \mathrm{~d}$, and greater in trees irrigated by two or three subsurface drip laterals than in trees irrigated with only one subsurface drip lateral. Irrigation frequency had little effect on tree size in the microjet treatments.

Production. Fruit were harvested on 25 and 29 May during the third growing season. Fruit tended to be somewhat undersized at harvest because they were picked early for better pricing.

The various irrigation systems had a significant main effect on fruit size $(P=0.003)$ and yield $(P=0.036)$ of the young trees, but not on crop load $(P=0.158)$, due to high variability of this characteristic within treatments (Table 4). In general, trees irrigated by microjets had fewer and smaller fruit at harvest, and consequently had significantly lower yields, according to contrast comparisons, than trees irrigated by drip or subsurface drip. Yields of furrow-irrigated trees were intermediate. Crop load, fruit size, and yield were not significantly affected by irrigation frequency in the furrow or microjet treatments, nor were they affected by the number of drip laterals in the subsurface drip irrigation treatments, even when trees were irrigated with only one lateral buried $2.4 \mathrm{~m}$ from the row (Table 4).

Fruit yields significantly increased in the young trees as more water was applied, regardless of whether the trees were irrigated by furrow, microjet, or subsurface drip systems (Fig. 1C). This was due to both higher crop loads and larger fruit sizes at higher irrigation levels (data not shown). Irrigation systems also had a significant effect on yield at the various irrigation levels. In particular, trees irrigated by microjets produced less yield per unit of water applied, otherwise known as irrigation water use efficiency (Bos, 1985), than trees irrigated by subsurface drip. Water use efficiency was intermediate in the furrow treatments.

\section{Discussion}

Growth and production of young peach trees planted at high density varied with the type of irrigation system used. Overall, trees irrigated by surface and subsurface drip outperformed trees irrigated by other methods during the first 3 years following planting (Tables 3 and 4). For example, when the same amount of water was applied across treatments, trees irrigated by surface and subsurface drip were significantly larger and produced higher yields than trees irrigated by microjets. Yields were also higher under surface and subsurface drip irrigation than under furrow irrigation, although tree size was similar among the treatments. Little difference was found between trees irrigated by surface and subsurface drip.

Some of the differences in tree performance among the irrigation systems were directly related to irrigation efficiency. More than twice as much water had to be applied to trees with microjets than to trees with other irrigation systems in order to achieve the same amount of vegetative growth (Fig. $1 \mathrm{~A}$ and B) and/or yield (Fig. 1C). Layne et al. (1996) similarly found that drip-irrigated peach trees required $\approx 50 \%$ less water than trees irrigated by microjets during the first 5 years following planting in Ontario, Canada. They attributed this difference to higher soil evaporation in the microjet treatments. Evaporation rates from a wet soil surface can be considerable after irrigation or rainfall, often exceeding evapotranspiration rates measured in well-irrigated grass fields (i.e., reference evapotranspiration), especially when the crop is small and shades little of the soil surface (Allen et al., 1998). In young orchards, long intervals between irrigations and irrigating in the evening will help reduce evaporative losses following microjet irrigations. The effect of evaporation on the irrigation efficiency of microjet systems, however, is expected to be less once the orchard is mature and has a full canopy cover. For instance, in mature kiwi vines, Holzapfel et al. (2000) found that evaporation was higher in trees irrigated daily by surface drip than in trees irrigated twice weekly by microjets.

Lateral placement was an important factor influencing success of the drip irrigation systems. Young trees irrigated with only one drip lateral buried between rows were less vigorous, although not less productive, than trees irrigated with laterals buried on each side of the tree row, or one lateral placed on the soil surface near the base of the trees (Tables 3 and 4). Presumably, root development was inadequate to extract all of the water applied with one buried drip lateral, as indicated by the water pond that formed on the soil surface. It remains to be seen whether root volume will be adequate to meet transpirational demand in the drip treatments once the trees have fully matured. Mitchell and Chalmers (1983) observed that peach trees irrigated by a single drip line developed more slowly after 5 years than trees irrigated by microjets because root volume was restricted under drip irrigation. They also observed, however, that fruit production was similar between treatments. Drip irrigation also increased production and fruit quality while reducing shoot growth, compared with sprinkler irrigation of apples (Proebsting et al., 1984). Several studies suggest that wetting only $20 \%$ to $50 \%$ of the potential root zone of mature deciduous fruit trees is sufficient to maximize yield, provided sufficient water is available to meet evapotranspiration requirements during critical periods of fruit development (Fereres and Goldhamer, 1990; Tan and Buttery, 1982). Restricted root systems, such as those limited by soil conditions or irrigation system design, may limit vegetative growth without limiting photosynthesis, thereby increasing availability of assimilates for fruit production (Boland et al., 2000 a, 2000b).

Irrigation frequency was expected to affect growth and production in the young peach trees. When irrigation intervals are long, soil water is depleted and trees are exposed to higher levels of water stress (Bryla, unpublished results; $\mathrm{Fe}$ reres and Goldhamer, 1990). Even mild water stress can induce fresh fruit weight reductions in peach (Berman and DeJong, 1996) and lower profits at harvest. Indeed, high-frequency irrigations using surface and subsurface drip may have enhanced fruit development over low-frequency irrigation systems, accounting for the yield differences observed between drip and furrow treatments (Table 4). The benefits of high-frequency irrigation have been well documented for annual crops (Bucks et al., 1981; El-Gindy and El-Araby, 1996; Phene et al., 1990). Within a given type of irrigation system, however, irrigation frequency appeared to have little effect on tree development and performance, particularly during early stages of development. Trees irrigated by microjet, for example, were not affected by frequencies rang- 
ing from every $2-3 \mathrm{~d}$ to every 2 weeks. Trees irrigated by furrow, however, were significantly smaller when irrigated every 3 weeks than when they were irrigated every 1 or 2 weeks (Table $3)$. Fruit size was also significantly larger in trees irrigated every 2 weeks than in the other furrow treatments, although this effect was undoubtedly influenced by differences in crop load among the treatments (Table 4).

The response to increasing levels of irrigation was similar among the irrigation methods examined. Whether trees were irrigated by furrow, microjet, or subsurface drip, growth and production increased as irrigation was increased from $70 \%$ to $150 \% \mathrm{ET}_{\mathrm{c}}$ (Fig. 1). In general, vegetative growth was particularly responsive when irrigation was increased from $100 \%$ to $150 \% \mathrm{ET}_{c}$, while reproductive growth responded more when irrigation was increased from $70 \%$ to $100 \% \mathrm{ET}_{\mathrm{c}}$. This indicates that, regardless of the irrigation system used, growth of young trees can be maximized during initial orchard establishment with heavy irrigation. However, increased irrigation levels appear to have less impact on early production and profitability. Mitchell and Chalmers (1982) came to a similar conclusion when growing ultra-dense orchards of peach trees in arid and semi-arid regions of Australia.

Early results indicate that drip and subsurface drip irrigation reduced evaporation and improved growth and early production of young peach trees over other irrigation methods commonly used in central California. In particular, trees irrigated with either one surface drip lateral (placed near the tree trunks along the row) or two subsurface drip laterals (buried on each side of the row at a distance of 1.1 $\mathrm{m}$ from the tree trunks) performed best. The present study will be carried out for at least four more years to determine the effects of these irrigation methods on productivity of mature trees.

\section{Literature Cited}

Allen, R.G., L.S. Pereira, D. Raes, and M. Smith. 1998. Crop evapotranspiration. Guidelines for computing crop water requirements. FAO Irr. and Drainage Paper 56, Rome.

Berman, M.E. and T.M. DeJong. 1996. Water stress and crop load effects on fruit fresh and dry weights in peach (Prunus persica). Tree Phys. 16:859-864.

Boland, A.M., P.H. Jerie, P.D. Mitchell, I. Goodwin, and D.J. Connor. 2000a. Long-term effects of restricted root volume and regulated deficit irrigation on peach: I. Growth and mineral nutrition. J. Amer. Soc. Hort. Sci. 125:135-142.

Boland, A.M., P.H. Jerie, P.D. Mitchell, I. Goodwin, and D.J. Connor. 2000b. Long-term effects of restricted root volume and regulated deficit irrigation on peach: II. Productivity and water use. J. Amer. Soc. Hort. Sci. 125:143-148.

Bos, M.G. 1985. Summary of ICID definitions of irrigation efficiency. Intl. Comm. Irr. and Drainage Bul. 34:28-31.

Bucks, D.A., L.J. Erie, O.F. French, F.S. Nakayama, and W.D. Pew. 1981. Subsurface trickle irrigation management with multiple cropping. Trans. Amer. Soc. Agr. Eng. 24:1482-1489.

Burt, C.M., A. Mutziger, D.J. Howes, and K.H. Solomon. 2002. Evaporation from irrigated agricultural land in California. Irr. Training and Res. Ctr. Rpt. R 02-001, California Polytechnic State Univ., San Luis Obispo.

Camp, C.R. 1998. Subsurface drip irrigation: A review. Trans. Amer. Soc. Agr. Eng. 41: 1353-1367.

DeJong, T.M., K.R. Day, J.F. Doyle, and R.S. Johnson. 1994. The Kearney Agricultural Center Perpendicular "V" (KAC-V) orchard system for peaches and nectarines. HortTechnology 4 : 362-367.

El-Gindy,A.M. and A.M. El-Araby. 1996. Vegetable crop response to surface drip and subsurface drip under calcareous soils, p. 1021-1028. In: C.R. Camp, E.J. Sadler, and R.E. Yoder (eds.). Proc. Intl. Conf. Evapotranspiration and Irr. Scheduling. Amer. Soc. Agr. Eng. Publ., St. Joseph, Mich.

Fereres, E. and D.A. Goldhamer. 1990. Deciduous fruit and nut trees, p. 987-1017. In: B.A.
Stewart and D.R. Nielson (eds.). Irrigation of agricultural crops. Agron. Monogr. No. 30. ASA-CSSA-SSSA Publ., Madison, Wis.

Goldhamer, D.A. and R.L. Snyder. 1989. Irrigation scheduling: A guide for efficient on-farm water management. Univ. of California Publ. No. 21454

Holzapfel, E.A., R. Merino, M.A. Mariño, and R. Matta. 2000. Water production function in kiwi. Irr. Sci. 19:73-79.

Johnson, R.S., J.Ayars, and T. Hsiao. 2002. Modeling young peach tree evapotranspiration. Acta Hort. 584:107-113.

Kruse, E.G., D.A. Bucks, and R.D. von Bernuth. 1990. Comparison of irrigation systems, p. 475-508. In: B.A. Stewart and D.R. Nielson (eds.). Irrigation of agricultural crops. Agron. Monogr. No. 30. ASA-CSSA-SSSA Publ., Madison, Wis.

Layne, R.E.C., C.S. Tan, and D.M. Hunter. 1996. Irrigation and fertilizer application methods affect performance of high density peach orchards. HortScience 31:370-375.

Mitchell, P.D. and D.J. Chalmers. 1982. The effect of reduced water supply on peach tree growth and yield. J. Amer. Soc. Hort. Sci. 107:853-856.

Mitchell, P.D. and D.J. Chalmers. 1983. A comparison of microjet and point emitter (trickle) irrigation in the establishment of a high-density peach orchard. HortScience 18:472-474.

Phene, C.J., R.B. Hutmacher, K.R. Davis, and R.L. McCormick. 1990. Water-fertilizer management of processing tomatoes. Acta Hort. 277:137-143.

Proebsting, E.L., S.R. Drake, and R.G. Evans. 1984. Irrigation management, fruit quality and storage life of apples. J. Amer. Soc. Hort. Sci.109: 229-232.

Renquist, R. 1987. Evapotranspiration calculations for young peach trees and growth responses to irrigation amount and frequency. HortScience 22:221-223.

Syvertsen, J.P. 1986. Integration of water stress in fruit trees. HortScience 20:1039-1043.

Tan, C.S. and B.R. Buttery. 1982. The effect of soil moisture stress to various fractions of the root system on transpiration, photosynthesis, and internal water relations of peach seedlings. J. Amer. Soc. Hort. Sci. 107:845-849. 